\title{
Digitalization as a method of implementation EEU transit potential
}

\author{
Elena Koroleva $^{1}$, Sergey Sokolov ${ }^{{ }^{*}}$, and Evgeniya Filatova $^{2}$ \\ ${ }^{1}$ Admiral Makarov State Uiversity of Maritime and Inland Shipping, St. Petersburgm, Russia \\ ${ }^{2}$ Admiral Ushakov Maritime State University, Novorossiysk, Lenin's avenue, 93, Russia
}

\begin{abstract}
In today's world digital solutions make life easier in various fields. Digital interaction provides a complete transition to automated systems and electronic document management, opening up new prospects for economic growth of the Eurasian economic Union, including the implementation of the transit potential of the Eurasian economic Union. The article considers digital solutions that can allow to develop the transit potential of the Eurasian economic Union, as well as identifies the existing problems of digitalization.
\end{abstract}

\section{Introduction}

In the modern world, digital solutions on the one hand simplify life in various fields of activity, ensuring the free movement of goods, services and human resources, on the other hand, play an important role in the competitiveness of separate countries and economic unions. Digital interaction leads to the restriction of the use of paper procedures, providing a complete transition to automated systems and electronic document management, opening up new prospects for economic growth of the Eurasian Economic Union (EEU).

The single digital market implies the removal of all national barriers in the digital sphere between the member States of the EEU to facilitate business, private purchases, access to information with a high level of protection.

In recent years, tangible progress has been recorded in many areas of digital development. The introduction of digital technologies in transport, logistics, cargo transportation administration and public administration will significantly help to improve the efficiency of transportation.

Realization of the transit potential of the EEU is a very relevant topic, which can be achieved through the development and creation of a unified infrastructure of the EEU, as well as by digitizing the logistics of such infrastructure. The prospects for the countries of the member states of the EEU are quite high, and the national programs contain promising indicators for increasing transit volumes, for the implementation of which the created flows within the EEU must be coordinated. Being a transit territory between developed and developing countries, large regional trade and economic blocs of Europe and Asia and

*Corresponding author: korolevaea@gumrf.ru 
having ramified paths for all types of transport, the EEU has significant transit potential. Member States actively export and import transport services, which occupy a significant share in the foreign economic turnover of services.

\section{Results}

The market of transport and logistics services in the countries of the EEU over the past year has shown significant growth, this was primarily possible due to the growth in cargo transportation (figure 1) [7]

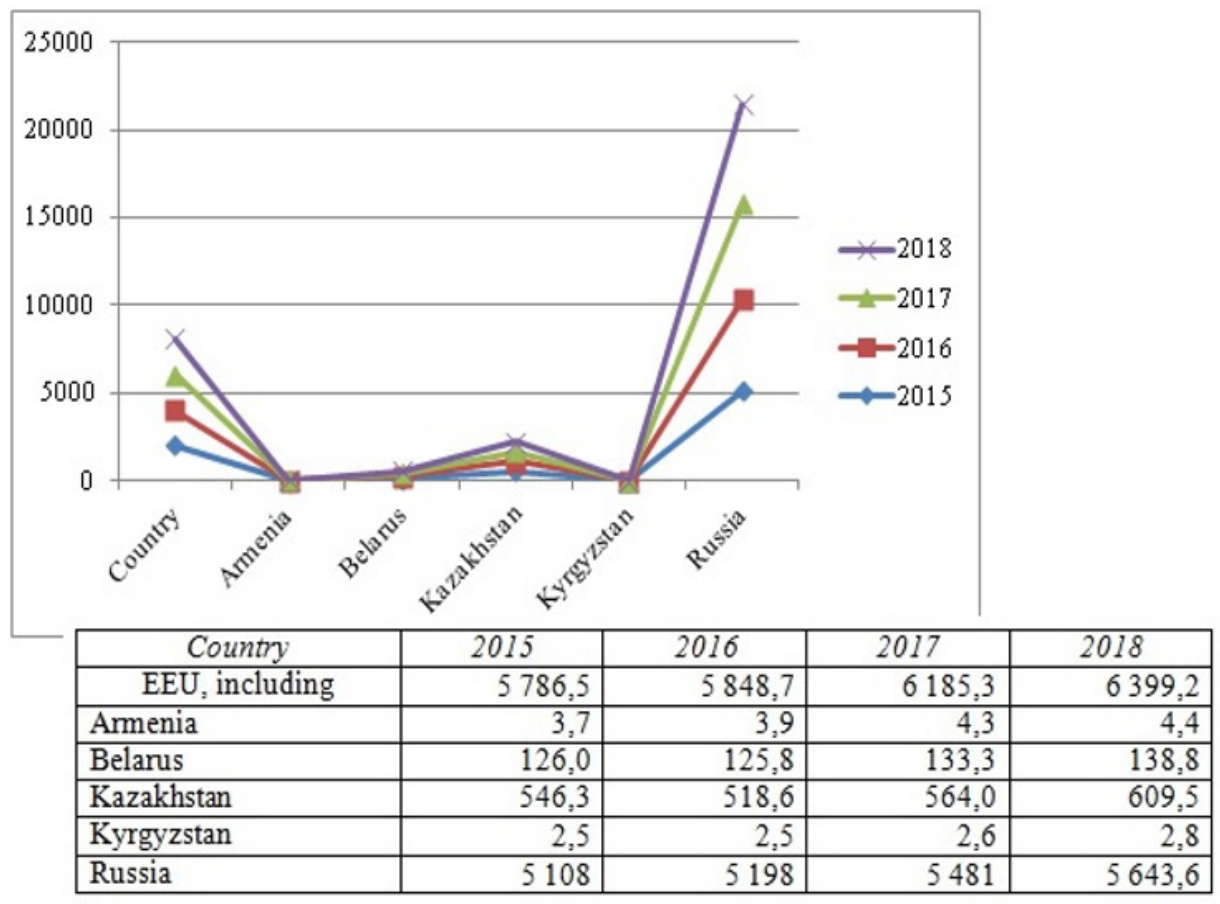

Fig. 1. Cargo turnover by mode of transport of the EEU countries for the period 2015-2018, billion tons-km

According to the EEU, the indicator of the volume of cargo transportation in the countries of the EEU since 2015 shows a constant growth trend, reaching 6.4 billion tons in 2018 (growth compared to the previous year was $103.3 \%$.) $[4,5]$.

The dynamics of cargo turnover by mode of transport (as a percentage of the corresponding period of the previous year) is presented in table 2 .

In January-June 2019, the turnover of all modes of transport of the member States of the Eurasian economic Union amounted to 3 trillion. 176.5 billion $\mathrm{t}-\mathrm{km}(+1.5 \%$ compared to the same period last year). The volume of cargo transportation (without pipeline transport) during this period increased by $0.7 \%$ and amounted to 5069.8 million tons. The volume of cargo turnover (without pipeline transport) in comparison with January-June 2018 increased by $2.2 \%$ and amounted to 1 trillion. 739.3 billion tons-km. the volume of cargo turnover in the EEC countries amounted to 3 trillion. 176.5 billion t-km: by pipeline - 1 trillion. 437.2 billion t-km, by rail -1 trillion. 469.5 billion t-km, by road-222.5 billion $\mathrm{t}-$ $\mathrm{km}$, by air - 3564 million tons, by water - 43 billion 921.3 million tons [6]. 
Table 2 Dynamics of cargo turnover by mode of transport (as a percentage of the corresponding period of the previous year) [4]

\begin{tabular}{|c|c|c|c|c|c|c|c|c|c|c|}
\hline \multirow[b]{2}{*}{ Country } & \multicolumn{4}{|c|}{2015} & \multicolumn{4}{|c|}{2016} & \multicolumn{2}{|c|}{2017} \\
\hline & 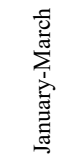 & 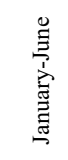 & $\begin{array}{l}\text { 灾 } \\
\text { 悹 } \\
\text { 总 } \\
\text { 总 }\end{array}$ & 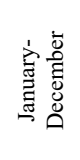 & 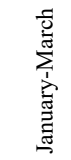 & 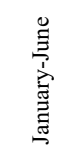 & 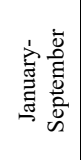 & 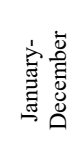 & 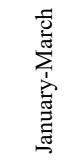 & 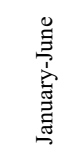 \\
\hline $\begin{array}{l}\text { EAEU, } \\
\text { including }\end{array}$ & 98,3 & 97,6 & 98,2 & 99,4 & 101,3 & 101,1 & 101,6 & 101,6 & 105,3 & 107,2 \\
\hline Armenia & 87,1 & 85,7 & 88,4 & 88,5 & 96,1 & 102,9 & 100,6 & 103,7 & 122,6 & 124,2 \\
\hline Belarus & 95,7 & 94,8 & 95,1 & 95,9 & 99,4 & 100,0 & 100,1 & 99,5 & 104,0 & 104,9 \\
\hline Kazakhstan & 97,7 & 94,4 & 92,8 & 92,5 & 100,3 & 100,9 & 100,2 & 100,5 & 105,4 & 106,9 \\
\hline Kyrgyzstan & 105,2 & 105,6 & 104,1 & 101,1 & 96,3 & 96,9 & 93,0 & 97,8 & 103,6 & 103,7 \\
\hline Russia & 98,4 & 98,0 & 98,9 & 100,2 & 101,5 & 101,2 & 101,8 & 101,8 & 105,3 & 107,3 \\
\hline
\end{tabular}

continuation of table 2

\begin{tabular}{|c|c|c|c|c|c|c|c|c|}
\hline \multirow[b]{2}{*}{ Country } & \multicolumn{2}{|c|}{2017} & \multicolumn{4}{|c|}{2018} & \multicolumn{2}{|c|}{2019} \\
\hline & 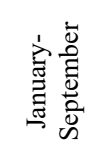 & 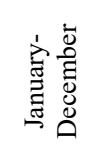 & 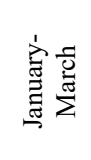 & 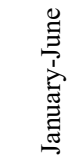 & 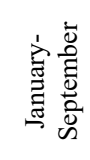 & 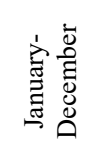 & 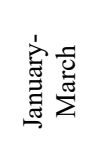 & $\begin{array}{l}\text { 壳 } \\
\text { 空 } \\
\text { 壳 }\end{array}$ \\
\hline $\begin{array}{l}\text { EAEU, } \\
\text { including }\end{array}$ & 106,8 & 105,7 & 103,2 & 103,5 & 103,5 & 103,3 & 102,0 & 101,5 \\
\hline Armenia & 117,2 & 109,7 & 91,0 & 96,1 & 104,0 & 103,2 & 105,1 & 104,8 \\
\hline Belarus & 105,2 & 106,0 & 107,0 & 105,3 & 104,7 & 104,1 & 98,7 & 92,4 \\
\hline Kazakhstan & 108,1 & 107,9 & 109,1 & 109,5 & 108,9 & 107,3 & 102,1 & 101,5 \\
\hline Kyrgyzstan & 107,2 & 107,1 & 106,1 & 104,5 & 105,1 & 105,2 & 101,4 & 103,1 \\
\hline Russia & 106,7 & 105,5 & 102,5 & 102,9 & 102,9 & 102,9 & 102,1 & 101,7 \\
\hline
\end{tabular}

The increase in cargo turnover, as well as the realization of the transit potential of the EEU, can be achieved through the development of international transport corridors, namely, through the operation of digital transport corridors, which, in accordance with the Decision of the Supreme Eurasian Economic Council of October 11, 2017 No. 12 "About Main Implementation Directions of the digital agenda of the Eurasian Economic Union until 2025 "is a priority initiative for the implementation of the digital agenda of the EEU [2].

The international transport corridor is a direction of concentrated cargo flows, mastered by one or several transport and technological lines, ensuring high-quality and timely delivery of export-import and transit cargo, which requires developed transport infrastructure not only in its own territory, but also in those states where their continuation lies. The possibility of using national transport communications to ensure international cooperation determines the importance of a particular section of the network for the transport of foreign trade goods.

International transport corridors are important for each country, the effective functioning of which requires the existence of well-established and well-developed transport logistics, involving the use of certain elements (a sequentially-central interaction scheme of participants, a single transport document, a single freight rate, high responsibility for the cargo). According to experts, the problem of the functioning of the international transport corridor is the prevalence of the "material approach" for the development of the transport industry; organization of paper workflow and reporting in the organization of 
transportation and foreign economic activity; insufficient level of implementation of modern technologies and digital services for coordination of the transportation process and interagency cooperation; information disunity, non-integrated information systems of state regulatory bodies, etc. [1].

Digital transport corridors are considered by experts as a system for collecting, processing and consolidating information about vehicles, goods and accompanying documents at all stages of transportation, technological operations. Such a format forms a developed package of digital services, and accordingly, as an information system, it assumes work in the "single window" format without territorial restrictions.

The digital transport corridor is being built as a distributed system of national transport logistics centers with the following functions:

- electronic interaction of system users during direct and multimodal transportation;

- monitoring and control of vehicles, cargo and operations with them; collection, processing and provision to users of the system of consolidated information on the condition of the cargo and accompanying documents during transportation;

- the provision of analytical reporting to users of the system and regulatory authorities on transit, export, import and domestic freight flows;

- providing new and improving the quality of existing services for all participants in the business processes of cargo delivery.

Digital transport corridors can increase transport efficiency. When translating state and other services into electronic form, the formation of legally relevant electronic accompanying documents is automated, as well as paperless documentation leads to a reduction in time costs and an increase in the speed of information exchange, for example between customs authorities.

Electronic customs for the model of managing uninterrupted international supply chains in the modern world is an important condition. The management of end-to-end supply chains allows us to assess risks to a deeper degree and to take measures to minimize them earlier, when they are necessary, which in turn reduces the need for physical contact with goods at customs points of release of goods at the end point of the route, and also allows you to track goods in chains supplies. The main operation relies on a secure exchange of information in real time between participants in foreign economic activity and customs and between customs administrations in the supply chain, which involves:

- interconnected systems and databases agreed by customs for electronic data exchange between customs administrations, as early as possible, on the international movement of goods;

- mutual recognition and coordination of electronic folders with files between administrations of export, transit and import to eliminate unnecessary duplication of control measures in international supply chains;

- a set of rules governing the exchange of information between customs administrations, including rules for the protection of information.

The customs authorities of the Eurasian Economic Union are striving for such an interaction, creating digital corridors to reduce time costs during customs control in international transport corridors.

The Eurasian Economic Commission has completed the development of the concept of creating an ecosystem of digital transport corridors of the EEU, which is to create an open ecosystem of transport and logistics information services based on advanced digital technologies and platform solutions, including those already existing, which ensure effective interaction of carriers and cargo owners in all five member states of the EEU, as well as from third countries $[3,4]$.

The creation of the ecosystem is aimed at solving problems in the field of efficient use of the accumulated transport and logistics potential of the EEU, including transit. In the 
market of the countries of the EEU there are isolated segments of transport information systems. The ecosystem of digital transport corridors is designed to unite them together, and make the transportation process as transparent, efficient and understandable for users of all levels: from cargo owners and cargo carriers and ending with regulatory authorities, based on the principle of national sovereignty of the data.

In the created ecosystem, cross-border interaction of services provided not only by public authorities, but also by businesses representing various sectors of the economy (cross-sectoral interaction) is organized on equal terms. In General, the ecosystem of digital transport corridors will optimize the processes of transportation and Declaration of goods, minimize barriers and increase competitiveness for bona fide participants in the transportation process, including by determining the most optimal routes and conditions of transportation, the use of legally significant electronic documents, optimizing the functions of state regulatory authorities, pre-booking the queue at the international road checkpoint and the formation of a unified information environment, including at the supranational level. As a result, administrative and time costs of carriers should be significantly reduced, while the speed of turnover of goods should increase.

The General principles of organization and information support in a single digital space of the EEU, increasing the efficiency of transport and logistics processes and their management will optimize the information interaction of participants and platforms of the transport complex, create prerequisites for mutual trust of the countries.

The practical implementation of the ecosystem of digital transport corridors will reduce the costs of the transport component in the final cost of products, ensure the quality and safety of transportation, increase the capacity of the international transport corridor of the EEU, its competitiveness and commercial attractiveness. For example, road transport currently provides in the countries of the Eurasian "five" more than $80 \%$ of the total volume of cargo transportation by transport. It is expected that due to the implementation of the digital transport corridors ecosystem project on international transport from 2022, the annual mileage per vehicle due to the reduction of non-production downtime will grow by an average of $20 \%$. Accordingly, the growth of annual revenue per car can average up to 12 thousand euros. The project involves a number of multiplicative effects affecting the growth of the economy of the member States of the EEU as a whole (preparation of the regulatory framework, implementation of pilot projects, technical design of national and supranational segments, development of standards and modernization of existing information systems), which will be implemented until 2025 in three stages.

As part of the digital transport corridor ecosystem, it is planned to maximize the use of existing or developing commercial and government platforms, including:

- system of customs authorities of the EEU;

- state platforms of transport complexes of the countries of the EEU;

- charging systems for the use of transport infrastructure facilities;

- commercial and logistic platforms and freight forwarding services;

- automated systems of carriers and services of logistics centers;

- financial and insurance services.

At the same time, new elements of the system will be added to the existing ones, for which pilot projects need to be tested (for example, route planning services taking into account all restrictions and control of existing permits) [4].

Interesting solutions that will stimulate to the development of the transit potential of the EEU are the introduction of a unified monitoring system for transit cargo transportation and the creation of a digital platform for transit transportation in the EEU countries. The latter is a single system that stores information about the movement of goods, from the place of its production to shipment to the place of final use.

Tracking with the unified monitoring system of transit cargo movement will be carried 
out by means of electronic navigation seals (the implemented pilot project has already shown its working condition). In order to transfer monitoring to a digital format, an effective exchange of data on transported goods between railway carriers of the Eurasian economic Union countries should be established. In addition, the member States of the Eurasian economic Union will exchange experience in customs control of transit goods for which one of the member States of the Eurasian economic Union has temporarily introduced import licensing [7].

\section{Conclusions}

Summing up, we can say that today a sufficiently large number of digital solutions are being discussed and adopted, the implementation of which will contribute to the implementation of the transit potential of the EEU. Nevertheless, there are certain problems, which include:

- the imperfection of the regulatory framework, including the speed of decisionmaking and implementation of legislation;

- coordination on the creation of common logistics corridors of the EEU;

- unification and mutual recognition of electronic documents in all countries of the route;

- the lack of a global automation product that meets the needs of all participants in the process;

- the lack of universal protocols of information interaction; training of specialists;

EEU;

- the backlog of infrastructure and technical readiness of the member states of the

- the lack of mass national production of transit flow management systems and others.

The application of digital transformations and complex problem solving will lead to the removal of existing obstacles and restrictions, which in turn will have a positive impact on the development of the transit potential of the EEU

\section{References}

1. Boreyko A.E. Digital «ecosystem» of international transportation corridor. Digital resource. Access mode. URL:

http://eec.eaeunion.org/ru/act/dmi/workgroup/Documents/tibo/4.\%20\%D0\%91\%D0\% BE\%D1\%80\%D0\%B5\%D0\%B9\%D0\%BA\%D0\%BE.pdf (request date 12.11.2019)

2. Decision of Higher Eurasia Economic Union from 11.10.2017 N 12 "About main direction of implementation digital agenda of Eurasia economic union till 2025 year"

3. Digital resource. Access mode. URL:

http://ac.gov.ru/projects/otherprojects/024553.html (request date 12.11.2019)

4. Digital resource. Access mode. URL:

http://www.eurasiancommission.org/ru/act/integr_i_makroec/dep_stat/econstat/Pages/ transport.aspx (request date 12.11.2019)

5. Digital resource. Access mode. URL:

https://news.myseldon.com/ru/news/index/217411272 (request date 12.11.2019)

6. Digital resource. Access mode. URL:

https://news.myseldon.com/ru/news/index/214768711 (request date 12.11.2019)

7. Digital resource. Access mode. URL: https://ru-

bezh.ru/gossektor/news/19/06/25/stranyi-eaes-sozdadut-edinuyu-sistemu-monitoringatranzitnyix-gr (request date 12.11.2019)

8. Filatova E.V., Golovan T.V., Tonkonog V.V. Journal «Labor and social relationship», 
№1 - Moscow: Educational institution of labor union « Labor and social relationship Academy», 2019.

9. Filatova E.V., Golovan T.V., Tonkonog V.V. Russian Customs Academy Bulletin. № 2 (47) - Lyubertsy: Russian Customs Academy, 2019.

10. Koroleva E.A., Sokolov S.S., Makashina I.I., Filatova E.V. Proceedings of the 2018 IEEE International Conference «Quality Management, Transport and Information Security, Information Technologies». - Saint Petersburg: Saint Petersburg Electrotechnical University «LETI», 2018.

11. Koroleva E.A., Sokolov S.S., Makashina I.I., Filatova E.V. MATEC Web of Conferences. 2018. Volume 239 (2018) 